\title{
Impact of Digital Media on Brand Loyalty and Brand Positioning
}

\author{
Rizwan Raheem Ahmed \\ Department of Business Administration, Indus University, Karachi \\ Rakesh Kumar, Mirza Zeeshan Baig, Muhammad Komail Khan \\ Faculty of Management Sciences, SZABIST, Karachi
}

\begin{abstract}
The objective of this research was to find out the importance of digital media and business to increase their revenues and market their products in a better way. Another objective of this research to differentiate between conventional and new media and to view the level of awareness about their concept among people. This research is exploratory and research design is qualitative in nature. We conducted interviews from different experts of digital media who are fully aware with latest trends of marketing. The findings of this research reveal that a wise marketing strategy can increase the market share of different brands in Pakistan (especially new entrants) in comparison of conventional media. It is concluded that the digital media has a key role in creating brand royalty since advertising has changed from traditional to digital so there is a much scope available in this area, consumer interest is increasing in this type of marketing platform in Pakistan, especially big companies like (Coca-Cola, Unilever, P\&G, Gucci) have successfully created their brand image and brand association by engaging various activities through digital media. In today's world digital media is important because it is cost effective, develop more awareness and also the queries put forward by the consumers are answered by the companies quickly. Through digital media companies constantly improve themselves and try to create a good image about the product.
\end{abstract}

Keywords: Digital Media, Brand Loyalty, Brand positioning, exploratory, marketing strategy

\section{INTRODUCTION}

Over the years the mode of communication change a lot as few years ago traditional media was the only mode of the medium for communication but now a days digital media prosper a lot. Digital media provides the marketers a mechanism through which they can interact and communicate effectively and cheaply. Today's challenges and increasing competition forces the marketers to think on a cost cutting budgets and come out of something creative in order to be customer oriented, so digital marketing is the one which facilitates the marketers with both to be cost effective and new mode of interaction with the consumers and consumers (Ahmed et al, 2014).

\subsection{Background of the research}

This study is an attempt to search the newest mode of communication for interaction by the marketers with the consumer that will be more integrated and accountable. So digital media have opened many new channel of communication and provide the opportunity to the companies for developing closer relationship between consumers and their brands. Companies can develop brand loyalty of their product with the consumer through the digital media with variety of ways and methods as it provide the new platform to the marketers. So creating awareness, persuading and building a lasting two-way relationship is also a challenge, which not only helps to gauge interaction with consumers but also assist in gaining their preference and hence developing a strong brand figure (Ahmed \& Saeed, 2012). Building a strong brand is significant as in the wake of competitive rivalry the brand with the strong impact lasts for an indefinite period of time, the need is to create loyalty among the consumers through whichever channel reaching the consumers. The need to focus on new channel is important; as it is possible the number of audience may be switching from traditional to new mediums hence the effectiveness varies respectively. With the aid of tools and measures now it is possible to certain extent to measure and evaluate the outcome of a particular marketing campaign hence providing marketers with better analysis of their efforts, here digital marketing does play its role. However the challenge remains for creating perceived distinctiveness of the brand, relevance, perceived quality and brand knowledge for letting the consumers know how brand works for them. The brand image plays its role for making the consumers satisfy their esteem and both work collaboratively.

The effectiveness of digital media is being utilized by the many companies of the developed countries but it is being ignored by the companies in Pakistan, as it a new dimension of involving with the consumer. So there is a lot of prospect for establishing digital marketing platform for marketing campaign.

\section{LITERATURE REVIEW}

This segment experiences various fundamental hypotheses of conventional advertising and advanced promoting to comprehend the choices concerning Design with Benefits' computerized showcasing activities. Especially, 
when it is a startup and has as of late entered into the business sector, it is vital to recognize distinctive promoting apparatuses to have the capacity to make a far reaching showcasing plan to achieve its target advertise particularly if there should arise an occurrence of Pakistan

\subsection{Marketing}

The essential capacity of promoting is to oversee client connections. As per AMA (American Marketing Association 2013) it is characterized thusly: "Showcasing is the action, set of establishments, and methods for making, conveying, conveying, and trading offerings that have esteem for clients, customers, accomplices, and community on the loose." The two fold objective/goals of advertising is to pull in new clients and keep and develop current clients by conveying fulfillment. It is a methodology by which organizations make esteem for their clients and construct enduring and solid client relationship keeping in mind the end goal to increase esteem from clients as an exchange (Armstrong 2012, Ahmed \& Saeed, 2014).

\subsection{Branding}

Kotler et al., (2013) states in their book that brands are more than names and images. They speak to the purchaser's discernments and sentiments about the item and its execution, so marks really exist in the personalities of the clients. Consequently, compelling and effective brands have high brand value, which mean the brand has a positive differential impact on clients. It is additionally a measure of the brand's capacity to catch customer inclination and dependability. In that capacity, organizations are precisely building and overseeing brands. Organizations, for example, Coca-Cola, Disney, and Gucci have made a brand, that is more significant than the genuine item or administration they deliver. Marks that have the most noteworthy piece of the pie don't have it in view of exceptional profits or solid administration alone, but since shoppers feel that they pick up some extraordinary esteem through the brand (Martin \& Brown, 1990).

\subsection{Brand Positioning}

Brand positioning elaborates everything that differentiate one brand from the other, basically it means it is a point of difference, it is a contrast between what you do a product vs what you do to the mind of the consumer, a well positioned brand is that which is considered best in some way by the consumer in agreement with positioning may not be permanent, many times brands need to be repositioned, a broader scope of it will elaborate you what the brand will do and what it will not do it will also help for your brand vision for 5 to 7 years, it investigates the real image of the brand as it exists in the mind of the consumer, it also supports new brands launches, to manage brand extensions and in line with umbrella brand, sub brand and single product brand, it is used by brand managers as a reference guide for internal use and for deciding the dos and don'ts for the brand, where as marketing managers use it, to understand the competition, it is also used by marketing directors to manage a category or portfolio, brand positioning statement (USP), the foot print, bulls eye, key(MARS), brand pyramid, brand finger print, positioning ladder(McDonalds) and brand key(Unilever) are different names for it (Nunnally \& Bernstein, 1994).

\subsection{Brand Loyalty}

On one hand brand loyalty occurs when a person get the same product or service repeatedly from the same source them from other suppliers in marketing view it is a consumers commitment for using the same brand continuously, in line with brand loyalty is more than simple repurchasing, true brand loyalty exists through relative attitude towards the brand, like if you are a brand loyal fan of company $\mathrm{X}$, you will buy company $\mathrm{X}$ product in response to company $\mathrm{Y}$ product no matter company $\mathrm{Y}$ product is cheaper or of high quality (Rangaswamy, Burke \& Oliva, 1993).

There are certain factors influencing brand loyalty, which includes awareness, quality brand association repeat purchase behavior are the key influencing factors of brand loyalty. It also depends on the brand equity defined by Farquhar (1989), the added value with which a given brand endorse a product according to Lassar, Mittal \& Sharma (1995), brand equity has been examined from a financial view needs the financial worth of a brand and a customer based perspective (Keller 1993), which normally leads to better brand performance both form a financial and customer perspective.

According to Aaker \& Joachimsthaler (2000) defined into four dimensions: Brand awareness, perceived quality, brand association and brand loyalty. So brand loyalty is the heart of brand value. In line with brand association, which connects the consumer to the brand through organizational associations, events, brand personality and product attributes. Whereas brand awareness effects the perception and taste

\subsection{Customer-Based Brand Equity}

Keller (2003) shows in his exploration that a solid brand might be fabricated by utilizing the client based brand value (CBBE) display as help. This model gives a benchmark to organizations to survey their brand-building 
exertions. As per the model, it includes four steps: firstly, securing the correct brand personality; also, making the fitting brand significance through solid, remarkable and great brand affiliations; thirdly, choosing constructive, open brand reactions; and fourthly, building brand association with clients that have extreme and dynamic unwaveringness. To attain these four steps, brand needs to secure six brand-building squares: brand remarkable quality, brand execution, brand symbolism, brand judgments, brand sentiments, and brand reverberation. The accompanying delineates how steps and pieces influence one another. At the point when the brand accomplishes the most important brand-building piece, brand thunder, the clients demonstrate a high level of devotion to the brand and energetically communicate with the brand and offer encounters with others. Brand reverberation happens after the greater parts of the other brand-building squares are created (Keller 2003).

\subsection{Digital Marketing}

In the wake of investigating the standards of showcasing this area focuses on characterizing computerized advertising and investigating its chances. The idea of promoting has changed with the development of the Internet. It has moved customers from magazines, daily papers, and even a few cases TV and radio to the Internet. As indicated by the Internet World Stats (2013), in 2012 the Internet was utilized by 2.4 billion individuals around the globe, and those numbers are expanding consistently. In the United Sates, the same number was 273.8 million clients and in Europe 518.5 million. The Internet is gotten to through workstations, as well as by cellular telephones, tablets, amusement reassures, and other compact gadgets. Hence, the new period of promoting has a computerized structure (Krill, 2013).

\subsection{E-Business}

With a specific end goal to comprehend plan of action of Design with Benefits it is critical to characterize the term e-business. It alludes to online transactions: offering merchandise and administrations on the Internet, either in one transaction or about whether with a continuous membership cost. Online retail firms purchase items and exchange them on the web. Utilizing conventional transportation techniques conveys physical items and advanced items, for example, programming and music, might be conveyed through the Internet. (Strauss \& Frost 2001). Which has gain the popularity among the Pakistani users, it also shows that other foreign investor interested in Pakistani markets because it belongs to Rocket Internet is one of the largest E commerce focused venture capital firms and starter incubators founded in 2007 gained visibility through eBay, linked in and Facebook etc.

Another example can be of OLX which operates in more than 106 countries recently gain popularity in Pakistani markets, which belongs the parent company Naspers so it also reflects at many foreign company to invest in Pakistani company. It is also doing a great job in online retail market in Pakistan, Pakistani cities have been seen a boom in retail online, an internet penetration of 29 million in Pakistan suggest that over $15 \%$ Pakistanis are online, these numbers may be small compared to other countries of the world but in absolute terms it represents a huge market.

Pakistani entrepreneurs have ventured into market products and services aimed that tapping into this online power in start these people try to sale their gadgets, books and gifts, now however food, DVDs, accessories, shoes, clothes and even groceries are sold online. According to Shayan who is CEO of home shopping every day 14 online stores register with a recent case azmalo.pk a web site selling electronics gadgets (Rocket Internet owned business) failed to operate due to the fact that it was too big to an investment for a new market, new online retail business have to take it slow and steady means online sale in Pakistan, having multiple challenges the major one is being payment, in all over the world people use credit cards for purchase where as in Pakistan there is concept of cash on delivery (daraz.pk and deal today are currently using it).

\subsection{Social Media}

This section head over the online networking angle in computerized showcasing, and distinguishes its potential outcomes for the organization. The general meaning of social networking as indicated by Kaplan and Haenlein $(2009,2010)$, is that, "online networking is a gathering of Internet-built applications that manufacture with respect to the ideological and mechanical establishments of Web 2.0, and that permit the creation and trade of User required. Peoples are using Facebook, Twitter, LinkedIn, YouTube, Instagram, Pinterest and MySpace. The main three are Facebook, Blogger and Twitter (Nielsen 2012).

As per Nielsen's study (2012) shoppers invest more of a chance on interpersonal organizations than on any viable classification of site. Roughly 20 percent of their aggregate time online was utilized on a (PC) and 30 percent of aggregate time online on a cell phone. Different gadgets, for example, tablets, diversion supports, handheld music players and tablets likewise expanded in fame for getting to social networking. What's more, Nielsen's (2012) study showed that social networking is not singularly joined from home, yet for instance, more than a large portion of individuals matured 25-34 use long-range interpersonal communications in the workplace. It additionally uncovered that social networking has in a broad sense changed the customer choice adventure. As 
such, the days when organizations could hard control brand informing and advancement shoppers along a direct buy channel have finished. Shopper choices and practices are progressively determined by the sentiments, tastes and inclination of an exponentially bigger, worldwide pool of companions, associates and influencers. It came up that 70 percent of the social networking clients hear others' encounters on the web, 65 percent research brands, items and administrations, 53 percent compliment marks, 50 percent express concerns and whines about brands and administrations, and 47 percent of them impart money related motivating forces (Nielsen 2012).

Nielsen's study (2012) found that social networking has a solid impact on pursuing everywhere throughout the world, yet it is the strongest in the Asian Pacific, Latin America, Middle East, and Africa areas. Roughly 30 percent of clients in these locales utilized online networking every day to take in more about brands, items, and administrations. Social networking has a solid potential to impact shoppers over all areas. This implies that social networking speaks to a tremendous open door for brands to addition brand mindfulness and positive support with shoppers.

Ryan and Jones state in their book (2011: 14) that the movement towards online networking is maybe the hugest late improvement in Internet advertising. It might be seen that social networking speaks to an extraordinary open door for organizations and brands to addition positive support with customers. Advertisers can affect their business by utilizing the reception and impact of online networking, and saddle the developing wages of developing markets, for example, Asia, Latin America, and the Middle East. The customers in these districts will use more cash online later on (Nielsen 2012: 13).

\section{RESEARCH METHODOLOGY}

This portion is shows an overview of the method used in the study. It includes research design, research population, research sample, research sample techniques, research data collection and research data analysis.

\subsection{Research design}

This research is qualitative in nature. The method of getting data is survey, which includes interview. We conduct interviews from different marketers groves of the industry and also ask series of question from the consumers in order to know our results.

Our research type is exploratory in nature and the research design is longitudinal, means track the participants over the extended amount of time and same people are studied at more than one time to record the development in growth. People hesitate to become the sample of these studies due to long duration.

\subsection{Procedure}

First we come up with a problem that we identified preliminary search. Once we find the problem then we conduct a deep search in the shape of the literature review and other secondary data. Based on our search we formulate the interview and questionnaire to conduct with the marketers and consumers. Once the interview has been conducted, we went for their search work on, conduct interview and record our findings. Therefore, we can conclude our findings by the help of conducted interview. At that time we can give conclusion and recommendations.

\subsection{Population}

Our population will be homogenous in nature. It includes the marketers, which are involved in the brand building activities or campaigns from FMCG companies and Consumers, which are aware of the digital media.

\subsection{Sample and sampling method}

We are applying simple convenience sampling in our research. We want to obtain the characteristics of population in our sample; with the help of this method we can easily achieve our findings. The sample size is dependent on the saturation level of our interviews (marketer of different FMCG and peoples related with digital media).

\subsection{Measurement selection}

Data have been collected from both primary and secondary resources. Primary research is a survey, which is, consists on interviews. We have conduct interview from different marketers of FMCG companies and digital media persons. While the interview have also been conducted to the consumers and experts of digital media. We have also collected the secondary data. The secondary research, which includes the journals, books, research papers and abstract from different sources.

\subsection{Variables}

These are the variables that contribute to our topic:

- Variety of channels: Digital marketing provide extensive area to perform marketing activities 
- Cheap as compared to traditional media: Digital marketing serves as cheap tool as compared to traditional ATL activities

- User-friendly. Provides consumer centric content which can be accessed flexibly

- More creative tools: Digital marketing serves as a creative tool for enhanced consumer experience

\section{ANALYSIS OF DATA}

The future of digital media in Pakistan is going to grow. The availability of smart phones at cheap prices is very helpful in bringing more and more number of people in the fold of technology. The technology industry is growing and people are investing in it because of the potential. They can invest their money in some other industry where they can see growth. There are a lot of online businesses that are flourishing in Pakistan like Daraz.pk, deal today and many others and without doubt the future of digital media is very bright and encouraging.

\subsection{Summary of Respondents}

\subsubsection{Respondent - I}

Basically, in Pakistan it is an increasing role, five ten years back it was not significant and was not visible but it has been increasing now, it does not mean that marketer has shift their market but they extent their role in market, marketer who market their product on mass media they are doing the mass media but they are also using the digital media tool because the traffic on digital media is increasing. Marketer cannot ignore digital media now, for them, both are the touch point, digital media and mass media.

Yes, it has the significance but in the area of brand positioning rather than in the area of brand loyalty, because loyalty comes after the brand experience and repeat purchase. I think digital media/social media is assumed to be the a non-serious, in general public people feels that it also un-ethical as well people use abuses languages and copying information design etc.

People/Customer have doubts on social media, as many people are using social media but do not buy any products through it because of doubts.

This question has two aspects first is "Will digital media get growth?" the answer of this aspect is yes it will grow and the second aspect is "for developing brand loyalty in Pakistan", I think first it will play the role of brand perception because it's more important secondly "will come the brand loyally?" Yes, it is very important and it will grow for developing positioning and it can control the negativity of your product at the forum to contact your customer, the best example of lays chips they used Junaid Jamshed in their adds.

\subsubsection{Respondent - II}

Digital media is playing a vital role for controlling not only different brands but also world's greatest economies. In today's world, to increase the prospects of success, we are required to market products to our customers from their lifestyle; understanding their aspects of accessing information and actually people are into digital stuff now a days. Digital world discourages the time consuming traveling and makes people access the information; they would like to access from the point they feel comfortable in and this is the reason digital marketing is successful. Also digital marketing improves and augment the relationship with existing and prospect clients for examples through, Social Media, Applications on devices, sites and advertisement in via messaging.

Digital marketing assists in catering the wider customer segment as it discourages the physical existence and interaction. It makes customers to communicate with the business directly, most of the times. Digital marketing is cheaper than the typical marketing we have been watching throughout our lives. Business and products are always available as there is no time constrain because the business has not conventional timings.

When a customer uses our products, it is not exclusively his preference to continue with the product but also the features reference above. To make the customers loyal, we need to tap them from the different possible ways to enhance their satisfaction, which is brand loyalty. We can advertise to make our product TOM but to make the clients loyal and to survive; we need to come up with new ideas and continue working on the product development side to set a distinct brand position.

In business, we always need to augment the segment of existing clients to make the product life cycle shorter in other terms to increase the sales and this is only possible when we create distinct brand equity and make more and more peoples, the admirers of our offerings. Keeping our products with a discrete image is going to compel our consumers to experience our product; rest depends on the consumer to become loyal to our product or else but we need to make sure we provide the best value to consumers with what exchange with us.

Not all the brands are using the digital marketing to promote the products but traditional ways. Digital world provides more information and prejudice reviews about the products so there is no way for the customers to buy a product, which has previously not, contented the client. Now, people are more digitalized by using the smart phones and social media. Access of information is easy and has not time limits. Products are there at the showcases for clients for 24 hours and 365 days an year. Actually, it seems like digital world was generated to target customers with no physical boundaries. Marketers incorporating the elements of love and emotions in the 
marketing tactics, makes the clients use their brands and become loyal to it where as the features of the products created a distinct marketing positioning and they way the products are advertised, the themes, the effects, the endorsements used in the brands building and advertisements it creates a difference and discrete brand positioning. But, we need to make sure in running the entire advertisement process that our purpose is to inform client with our offering not disturb him but repeat message else client might become reluctant to use our brand.

Marketers play a very vital role and without them the marketing process either by digital means or traditional means would not be possible. With the introduction of digital media, the access to information increases and everyone has right to access information related to products, services and the companies offering them. This makes the marketing process easy for marketers. Now they can easily advertise the products online or using any other digital media medium they wish to.

When we play our advertisements on TV; we are not sure if the target segment has watched it or not. Using Social media and messaging; we can reach directly to the targeted segment on individual basis and to introduce our offerings to them. This can help us introduce the product to the right market with the right statistics that how many visitors, with what age group, with what educational backgrounds, which what hobbies or leisure activities and from which location they have seen the advertisement.

Marketers always want to know consumer insights and social media (\# tag integration), Blogs, Websites, forums has made it possible to sit and watch what people are saying about a new marketing campaign. This also helps us improve our product as per customer reviews and show them with a personalize feel that yes! We are watching you having our products. On the other hand we can see if our marketing campaign is getting successful and what areas are waiting patiently for us to launch our campaigns.

Peer pressure and influencers exist in all the societies, using celebrity endorsements, blogging, and socializing on social media influences other people to experience our products in other terms we are getting more and more consumers to taste the essence of our product.

One of the reasons for frequent and repeat purchase is to make the brand top of the mind when we think of the need it caters to; whereas the social media advertisement is going the same thing. We are into social media now a day and most of the people in our society are using the different social media websites to get connected with their loved ones. During their process of socializing with their beloved which is a moment of happiness most of the times, if we advertise the product somewhere on the application or on the website without disturbing them, it is necessary that it will take a good place in mind of customer and he might purchase the product or might be able to recall it.

In a country Like Pakistan, where we have IT industry on its peak, the social media and other digital aspects of marketing are growing, People are now taking the education as a serious matter, the number of people accessing the internet for the sake of quenching their thrust to obtain knowledge from digital source, the Launch of $4 \mathrm{G}$ service has augmented the use of internet and also the consumers, the accounts on social media are increasing and the businesses are into developing the websites designed to get more clients to sale the products so, there are positive prospects that digital media will continue to grow which is going to make a positive and significant impact on the brand loyalty of the products which are used to promote through digital means.

The Pakistani digital media is growing like anything after the launch of different digital services; people have more access to website, social media, Blogs and digital world. People are now into studying things before they actually consume it; rather than traditional or random buying.

When a new product comes to the market, one of the most important aspects to make the product successes, if the offerings are distinct or the way, the product is advertised in front of consumers and competitors; is different and it is going to make the product acceptable as we have thousands of products being advertised at the same time. On Digital TV or on online access; Playing with the best possible collection of offerings and emotions, we need to come up with an advertisement which make the product top of the mind and consumer is able to remember when here is a time to make the decisions on the respective need.

Even what we offer does not differs with the competitors then it depends how we offer it, this is going to create a competitive advantage because at times pioneers become less successful and followers take the lead because of the best communications skills and core/intense study of the target market. Integration of a uniform theme is a must have thing to introduce our client to the fantasy world of our products.

People are signing up on social websites; using Internet to access information in fact in South Asian countries the ratio of accessing information for the purpose of getting the knowledge out of it is increase to an unbelievable percentage. People are using digital media to look for deals, new offerings and to experience new products provides them best value. Far Behind all this race of information access and best value search, Digital media is gaining the popularity and getting dense day by day.

Traditional media is playing a very significant role and it has been playing a momentous role from centuries, as it was the sole mean to inform consumers about the offering. But now the era is of specialization, people do not want to view and know what they do not like and what they do not belong to. Using the specialized and customized advertisement to the targeted market can bring out the best outcomes. 
In today's world, the competition is on its peak and businesses want to cut down cost to the optimum keeping the current or best possible quality. The social media marketing, which is cheap but needs consistency, is showing more refined results then the traditional media. Keeping out product marketed by traditional means will not take down the business or demand but will decrease the growth rate. To be successful in today's world we need to we cannot just emphasis on either of the media but we need to market our products with traditional media as well as digital media to view the astonishing and synergic increase impact of our product demands.

Brand positioning is all about creating a divergent/positive/motivational image in the mind of people for our product. Now a day, where people are bombarded with lots of advertisement, even if we come up with new ideas, the traditional means of promotions are so thick that we cannot solely rely on them to bring us good results but we cannot even work without them either. Actually, our marketing expenses are going to increase if we want to focus on a broader side of clients and higher side of sales figures. Basically, it depends on what category does your consumers belong to. If we discuss software here, we would be advertising less on less digital means and more than $95 \%$ of our marketing/ advertising expense on digital means to target the client from where they would like to be targeted. But, we cannot solely reply on any of these.

Big IT Companies like GoDaddy and Blue Host are now advertising on TV to gain more market share by delivering their message to a broader audience from all possible means. BIG FMCG Companies are advertising their products on social media/website and blogs. We cannot simply reply on the traditional neither digital means, to promote our products. We need to use both of them to promote our products but the ratio of our marketing expense is completely dependent on the analysis of our consumers and product whether the client/product are high tech. or not. If they are high tech. we are for sure investing more on the digital means of promoting our products else on the opposite condition we would be investing more on the traditional means of prompting the products.

Either it is Digital media or any other traditional marketing media; it needs consistency and a good number of viewer or users to respond to it. Putting up hoarding, designing brochures, running massive marketing campaign, making client experience out samples, makes a lot of money but requires a lot of money as well. People who are not at all interested in watching our advertisements would also be watching them. We see huge cost sink when we talk about traditional media in a way that life now a day is fast and no one has time to what watch these traditional promoting structures. On the other hand, Digital media is cost effective in a sense that we actually safe printing cost, less people work on the backend so we save salary expense, managing these people would be easy so we are saving the managing cost.

As far as the efficiency is concern, when we talk about digital media, we talk about specialization; we can deliver our message to the right person at the right time example is Google AdSense and Facebook. Our interests are saved in cookies of our browsers and that makes these big companies understand what exactly we are looking for and they offer us the ads up to our need and this makes the process really smooth. And if we buy once and product is pursuing we will buy more and become brand loyal. Similarly, Clear Men Shampoo is running their advertisement in tubes prior the video plays and other social media are also doing it; they are targeting Men so they ads are only visible to men and only men are able to access that as the ads are shown as per the gender mentioned in the social media profile. After all this analysis, it is easy to understand a bid that digital media is less expensive than traditional media means of promotions.

\subsubsection{Respondent - III}

Digital media is playing a significant role in business promotions now a day in terms of reach ability of the producers to the consumers through affective marketing by using different sources of media like TV, Radio, Email, Internet and Social Media.

Brand loyalty depends on the promotion, which develops the image and position of the brand in consumers mind by using various marketing strategies. If the presentation of the promotion is comparatively impacts the value of his money through the advertisement; the relative loyalty will be developed for large. Digital media works as the most effective marketing tool in order to present the product in vocal as well as pictorial which impacts deeply on the perception of the consumer, which develops the loyalty along with the positioning of particular brand.

Marketers use the different strategies of marketing to expand their outreach among the masses. In today's scenario the digital media is in use to approach the maximum populace of any cadre, which directly affects the sale of marketed products. Digital media is the most growing industry with the high number of viewership increasing on daily basis, which also works for developing loyalty towards the brand by repetition of the marketing ads on digital media.

Digital media creates an image on the consumer with effective publicity of the products which posses its significance in terms of growing the positioning of brand, Digital media also gives the opportunity to the viewer for comparing the best among various advertised products. Marketing opportunities cannot be lemmatize to the available recent resources, a good marketer always remain in search of new mediums to approach its audience, apart from that; brand needs the quality as well to compete and develop the loyalty in the consumer. 
As stated above, quality of the product is an essential instrument for developing the position of brand; marketer cannot only rely on the media or other marketing strategies. Digital media is not that much cost effective but in relation to its outstretched viewership; it valued the money spent on advertising. Other than that the quality of the advertisement as well as advertised product pays in large later on.

\subsubsection{Respondent - IV}

The last 8-10 years digital media has been on rise in Pakistan through web and software development. The digital media industry has been relatively successful in Pakistan. However, the digital media has incorporated social media trends in Pakistan. Digital media includes social paradigms, web designing, micro sites, web sites, social applications. These applications are connected to digital media through digital devices. The buzz really started when social media becoming an important part of peoples life in Pakistan.

In terms being part of youth market brands on digital media have always focused on the age bracket of 15-25, which is a good bracket for a lot of brands be it FMCGs or other relevant products. And you know that this bracket is the one, which can be capitalized on, and you know that you can really hit their brains faster than a bracket below or above the 15-25 age group brackets. This segment is either the influencers or has the potential to buy the product. This segment will always be the center of focus for all the brands.

In terms of brand loyalty in new media or digital media is that "If you are not online you don't really exist". This is like a paradigm, which has been in market for some time. And this is how it works you recognizing people and you do research on other people. Like this is how it goes When companies wants to hire new people these days they won't be asking companies about your reference check they would simply go online and enter your name find out about you, what you are doing? What is your existence? Where you topped the most? Which forums you are on? They can find all this information online. You have open profile on different social Medias. Some people have their own websites to market themselves, which is a smart idea. This is how brand loyalty and branding came into being in digital media. The brands at least these days what they do is open their social forums, micro sites, websites, mobile applications one way or the other to communicate with the youth market that we are out there that we exist as entities. So what they are trying to do is to make people aware that particular brand is communicating with you. So either they are trying to sell their product or promoting themselves. How you find out any particular brand is there you simply type its name on any social forum and get to know if they are available there or not and this is about brand loyalty in digital media. People generally have brand loyalty but to promote them on digital media like coke, Ariel, detergents and other FMCG products they even have their social platforms to promote themselves. Digital media helps promotes two way communication because loyalty has already been established they are just there to further enhance and build on the loyalty that's already there.

New media really push forward and became successful only on the notion it is faster to communicate and its cheaper and can accommodate a lot of things which a brand wants to do, however it has few drawbacks but the thing is old media requires a lot of money buy off a lot of spots, fighting a lot of competitors and push yourself and reveal yourself on these out door mediums due to which it is very expensive and this is how conventional media works. It takes a lot of time, extra efforts and hassle to push yourself and media houses help you to get the right time and right spots and even then it doesn't gives you a sure fire guarantee that what numbers that particular campaign is generating to you how GRPs and stuff is calculated. All these things are based on assumptions for example a household of four people multiply that with certain numbers then they give you a figure. But with digital you are sure-fire connection every person comes and clicks and views your advertisement. On your website you have entire portfolio of your product. Through research software you can tell that how many people came and viewed your website. What pages they visited for longer period of time and so on and forth. In other words digital media provides you with exact numbers of views. That entire real time data made available through the research software can tell me the exact numbers and that date would help me in my future campaigns. And with the help of this data I can design my next time accordingly. Through trends in digital media it helps you in branding.

In terms of brand familiarity it's the same question again how much you can push yourself in the channel? Social media is of course a stronger channel in digital media to create brand familiarity. Twitter creates a good level of familiarity especially when it comes to serious brands. And now in Pakistan Facebook is not considered as a serious promotional tool. Twitter on the other hand is considered to be a certain form of elitist social tool. In that sense people are more serious about how to promote their product and talk on twitter being specific about Pakistani scenario. To create a buzz or trend and awareness about you on twitter is relatively faster and connective to do it on twitter. Because people think that if it is being promoting on twitter it is more serious in nature. Trending on social media specially twitter helps in creating familiarity through the past campaigns and through trending consumer comes to know that these companies are present and that's how trends work in branding. The hash tag (\#) tells consumer about the ongoing media campaigns and people tend to connect with that particular hash tag. Good and smart brands will join the hash tag as soon as possible but it doesn't guarantees retweets and but can make you part of a bigger movement a lot of people will connect with you. 
Numbers actually gives you of insight of how much brands can really look forward to connecting with social and digital media. There are about 31 million Internet users in Pakistan that's a big number. In terms of social media its 11.8 million people in Pakistan. These numbers reflect that most of people in Pakistan are using Internet and many have switched to smart phones and which is helping businesses to flourish on digital media. Putting these numbers in front it can be rightly said that a lot of number of people are connected to Internet through smart phones and are being familiar to those social applications and they are the potential users of the big brands. And being marketers it is always the potential users that need to be targeted for the benefits of future prospects. And keeping these potential users in sight companies caters to them and makes them loyal customers as well. In the last year there was an $8 \%$ increase in the number of Internet users.

In businesses the first and foremost thing is price. If you go to a client and they really like the idea. If the client is told that certain idea will be executed at certain amount but that amount is beyond the budget allocated by the client then the deal cannot be executed. Money always matters a lot in every business. In social media it is very cheap its approximately $5 \%$ of the amount compared with traditional media. Creating your own websites is very cheap compared to billboards or other methods of traditional media.

To push out a one click add on Facebook it costs you about 13 cents. That's nothing considering the users of Facebook and its impact. On social media the amount spends is very minimal amount and it is something businesses are looking forward towards. Brands as businesses everywhere are looking into costing cutting. And cost effective aspect of digital media is very attractive for brands and also its very targeted. But with conventional media you cannot be that targeted and not it is cost effective at all. Advertising on digital media is very precise and cheap. Any new initiative in business is a risk. And you know change is resisted in the initial phases. And businesses were not really sure whether customers would like the idea of their brands going online. $14^{\text {th }}$ street pizza started their business on Facebook and now you can look where they have reached today.

To conclude how digital media has had an impact it is very clear from the numbers stated above. The future of digital media in Pakistan is going to grow. The availability of smart phones at cheap prices is very helpful in bringing more and more number of people in the fold of technology. The technology industry is growing and people are investing in it because of the potential. They can invest their money in some other industry where they can see growth. There are a lot of online businesses that are flourishing in Pakistan like Daraz.pk, deal today and many others and without doubt the future of digital media is very bright and encouraging.

\subsubsection{Respondent - V}

We know that the media and marketing landscape is quickly evolving from what it was only about 5-10 years ago. Current business leaders are quickly adopting new methods of marketing themselves and their businesses but many are still confused as to why they really need to do this. All they really know is that they have to. It is also safe to say that most of these current business leaders are of an older demographic that ranges from ages 30 and above. So to cut to the chase, the reason these business leaders need to adopt digital media strategies is for the simple fact that the next generation of consumers is quickly maturing and future generations will likely continue on the same course of media consumption. People born after 1990 have never really known a world without the Internet, cell phones or digital media. This age group relies on digital media more so than any other age group. They consume gigantic amounts of information because it is readily accessible at their fingertips and in easy to understand formats. Now, this is not to say that all the information they gather on the internet is completely accurate or true but the mere fact that they consume so much media is an important point that marketing managers must note.

Like I said, people born after 1990 have never really known a world without the internet, cell phones or digital media that they consume so much media is an important point that marketing managers must note. While excellent and innovative products and stellar customer service are key requirements to building a loyal fan base, social-media marketing can help nurture and strengthen budding customer relationships.

Here are some tips to help you create social media content that can help turn casual followers into loyal and dedicated customers:

1. Interact

2. Be helpful

3. Make your fans the star

4. Offer perks

5. Be transparent

A key benefit of creating awareness via social media is its measurability. Here are some key awareness metrics to keep in mind.

- Potential reach. The numbers of fans, followers, or "eyeballs." It is more accurately seen as potential reach, as you'll never have all of those people paying attention to you simultaneously.

- Mentions per time period. How many times your brand is talked about online during a given time period. This can give you a sense of overall awareness and chatter. 
- Inbound links. A solid indicator of the people that are aware of you and are telling others about you. Look at the sites and media types where the inbound links live to get a sense of the types of media that are driving consistent attention for your brand.

- Share of voice. How much you're mentioned or covered in comparison to the competition.

- Share of conversation. How often you are mentioned in context of the conversations that are most relevant to you.

Well, it could be argued that they can complement one another well, and each has their own unique aspects. A quick overview of the main differences between Traditional and Digital Media:

\section{i) Traditional Media}

- One to many communication

- Mass marketing that's not targeted

- Monologue message

- Focuses more on branding than communication

- Supply side thinking

- Customer as a target

- Segmentation

- Mainly offline techniques

- Aims at mass awareness

- Doesn't use many insights or data for decision making

\section{ii) Digital Media}

- One to one or many to many communication

- Personalized, mass customization and targeted

- Dialogue

- Focuses more on communication than branding

- Demand side thinking

- Customer as a partner-CRM, feedback

- Communities

- Predominantly online techniques used

- Awareness created through targeting

- Uses customer insights and data to help with marketing strategies and decisions

To build brand familiarity requires persistence and a strategy that includes a variety of marketing tools intended to enhance brand recognition. A strong brand fuels consumer expectations that need to be satisfied. Consumer expectations are, directly or indirectly, associated to: a) past buying experience; b) brand associations; c) individual beliefs about the organization; d) the organization's marketing and promotional strategies; e) the competitors' positioning. So yes digital media can have an impact.

Not much time because the next generation of consumers is quickly maturing and future generations will likely continue on the same course of media consumption. People born after 1990 have never really known a world without the Internet, cell phones or digital media. This age group relies on digital media more so than any other age group. They consume gigantic amounts of information because it is readily accessible at their fingertips and in easy to understand formats. Now, this is not to say that all the information they gather on the internet is completely accurate or true but the mere fact that they consume so much media is an important point that marketing managers must note. Not only are social media campaigns economical (and often free) to implement and track, they can assist in bringing down overall marketing spending as well. This is particularly relevant for regional businesses that, using social media such as Facebook, can target exactly who they need to base on audience demographics.

Social media marketing is an optimal solution for businesses that are looking to save money but still communicate with its customer base. There are many different social media platforms that allow companies to showcase their products or services at a low cost. Yes. Many companies in Pakistan are utilizing social media marketing. The major industry that I think is the fashion industry that has best taken advantage of this platform.

In Pakistan not a lot of companies have their own websites and those that do only provide basic functionality, apart from that lacking online skills, limited internet access, not having time, absence of relevant skills, lack of interest, belief that digital is not worth the investment \& security concerns are some of the basic factors of reluctance toward digital media.

Now is the best time for Pakistan to move towards digital media. Brand loyalty has increased after the introduction of digital media, social media due to one on one interaction, offering perks \& being transparent, etc. Any business can reach to millions of people through digital media. An optimized website along with marketing activities can target the customers and rive in more traffic to the website. You can attract more customers who 
are interested in your products or services through marketing. The key facts to start up and expand your business are as follows:

- $\quad$ Target your customers

- Engage yourselves in online communities

- Converse with audience

- $\quad$ Educate customers about products

- Open up new ways to expand business

The growth I think will be seen in brand loyalty due to digital media and not vice versa. As the digital media grows more \& more brands are going to use the platform to develop their brands as we can already see across the globe.

\subsubsection{Respondent - VI}

Everything connected with the latest technology is a part of digital media. All these things of digital media are connected through technology. Like smartphones, smart TV and etc. have the increased the possibility of connecting with digital media. If there is a marketing campaign then on an average $3-4 \%$ of that campaign is on the digital media. In the coming years this amount of advertising on digital media will be on the rise In the Pakistan context it can be said that with the arrival of $3 \mathrm{G}$ and $4 \mathrm{G}$ technology it can greatly increase these number within the next few years. The Internet penetration in Pakistan is approximately $10 \%$ and $18-19 \%$ in other developed countries which is a huge a difference. But the number of Internet users today is almost close to 32 million, which is more than the population of Australia. Growth of Internet users from last year is $8 \%$ and with the launch of $3 \mathrm{G}$ and $4 \mathrm{G}$ in Pakistan the growth in the Internet users will exceed $8 \%$, which was witnessed last year. Because of this the advertising budget of big companies on digital media is surely going to riser in the next few years and they can accurately target their potential users through digital media.

Social media is a sub part of digital media. Digital media includes social media, application development, and display ads over the Internet. Young generation, which falls between 18-30 age group. And it is approximately $65 \%$ of our population. So it can be said youth are the influencers, help in idea sharing, followers and they also help in establishing two-way communications between consumers and the companies. Youth is the active population in social media and social networking websites can be used to attract and interact with the youth at the same time. Digital media is not just for youth it's basically about target population based upon demographics, psychographics behavior. It can be rightly said that with digital media you can target anyone not only focusing on the youth. Digital media can be for a child as well as an adult whereas traditional media was mass market oriented. And with digital media you can cater to every segment needs and wants in a better way.

Now a day big companies are not focused on time slot on television or specific program the companies are focusing on variety of ways to put their message across to their customers through traditional and digital media. Basically the concept digital media is integrated communication taking onboard all the communications of together on a single platform of digital media.

Brand loyalty in context of digital media is one thing not working in Pakistan because the campaign are mostly short lived Specially in the case of small brands. Basically there are a lot of other genetic brands already there on digital media so it's hard to create brand, as they're a lot of brands and choices available to the consumers. But the big brands like Coke, Unilever, Pepsi and others which are present in the markets for decades and have created brand loyalty and also they are round the clock active on digital media platforms and not only that but these big brands are consistently innovative as well with their advertising campaigns. In digital media there is freedom of speech to the consumers as they can communicate both their liking and disliking to the company through two-way communication. This is a great tool for the companies to improve themselves if there are any shortcomings. This in return increases the brand loyalty for that particular brand. And word of mouth and viral communication through social media

In terms of loyalty digital media is a just a tool everything depends on how you market and position your product. And the best important part is the word of mouth, which is done without; any money paid to the users and they share the advertisements and other stuff, which they like at the digital media.

Digital media plays an important role in creating awareness for a particular brand because basically it's a promotional tool and it does helps in awareness like if you saw commercial on television and the same commercial you get to watch online and that the former one can be shared through internet and it can greatly reach large number of audiences in no time but this is not possible in case of a watching a commercial on television.

Difference between digital and conventional media it's about reach depending upon the Television and social/digital media. Traditional form of marketing is there that is newspaper and other outdoor media and they are there and cannot be omitted and Television is somewhat on revival due to certain programs and shows but we come to digital media is all together a different ball game. 


\section{RESULTS AND DISCUSSION}

The purpose of this study was to clarify that the companies in Pakistan who can get Benefits are overlooking the role of digital media could take advantage of digital marketing more effectively in their overall marketing strategy. After an in-depth study of the theory of traditional marketing and different aspects of modern marketing and trends, the indisputable fact is that the future of marketing is increasingly shifting towards the online world. There is plenty of literature, research, and statistics available on marketing, as well as digital marketing, and the main focus was to gather a comprehensive theoretical foundation for the study based on this information. The target market-related articles, statistics, and surveys were also extensively used when evaluating the overall prospects. Among these sources, the study involved gathering primary data through discussions and emails with questionnaire, which is attached in appendix.

Nielsen's (2012: 10) survey showed that social ads were influencing purchasing behavior, for example, social media when making purchases in the clothing and fashion sector influenced 58 percent of respondents. Naturally, marketers need to move to where they can interact with the consumers, which nowadays involves the Internet more and more.

We found that most of FMCGs firms are not so much interested to invest in digital media, because normally they are targeting housewives and head of families with traditional media who have power to take decisions about their purchases. But mangers of FMCGs proud to use digital media while purchasing/selling their specialty products like car, house and furniture etc. on Olx.com, darazpk, and other sites like that. We explore that youngsters are motivated to use those products which are advertise through digital marketing because firms who uses digital media are giving 24/7 services to their customers, current trend of youngster are sleep late in night.

Digital media is the most growing industry with the high number of viewership increasing on daily basis, which also works for developing loyalty towards the brand by repetition of the marketing ads on digital media. Brand loyalty and positioning comes with time after we put our products on the red carpet for our clients. The Launch of $4 \mathrm{G}$ services has augmented the use of Internet and also the consumers, the accounts on social media are increasing and the businesses are into developing the websites designed to get more clients to sale the products.

Basically digital media or any other traditional marketing media; it needs consistency and a good number of viewer or users to respond to it. Putting up hoarding, designing brochures, running massive marketing campaign, making client experience out samples, makes a lot of money but requires a lot of money as well.

\section{CONCLUSION AND RECOMMENDATIONS}

\subsection{Conclusion}

It is concluded from this research that the digital media is playing a key role in creating brand royalty since advertising it has changed from traditional to digital, so, there is a much scope available in this area. As it is very much clear from the research that consumer interest is increasing in this type of marketing platform most of the companies in Pakistan, especially big companies like (Coca-Cola, Unilever, P\&G, Gucci) have successfully created their brand image and brand association by engaging various activities of digital media.

In today's world digital media is important because it is cost effective, develop more awareness and also the queries put forward by the consumers are answered by the companies quickly. Through digital media companies constantly improve themselves and try to create a good image about the product. Digital media is growing in Pakistan as the number of people using Internet is on the rise. Keeping this in view companies can increase their customer base and build upon the loyalty that is there among their existing customers.

\subsection{Recommendations}

1. Targeted activities can be easily achieved through the use of digital media in Pakistan.

2. The more people are aware with these types of digital media, the better results can be achieved.

3. In Pakistan people can initiate CSR activities through this type of media.

4. With the arrival of $3 \mathrm{G}$ and $4 \mathrm{G}$ the scope of digital media rise and will get a bigger share in the marketing campaign.

\section{REFERENCES}

Ahmed, R.R., Vishnu, P., and Amin, M.A, (2014), "Impact of Product Packaging on Consumer's Buying Behavior", European Journal of Scientific Research, Vol. 122 (2): 125-134.

Ahmed, R.R., Ahmad S, (2012), "Pharmaceutical drug promotion in Pakistan: Issues in ethical \& non-ethical practices", Interdisciplinary Journal of Contemporary Research Business, Vol. 4 (4): 968-990

American Marketing Association Homepage, 2013. [Online]. Available at: http://www.marketingpower.com/AboutAMA/Pages/DefinitionofMarketing.aspx.[Accessed21 June 2014]. 
Armstrong, G., Kotler, P., Harker, M. and Brennan, R., (2012), Marketing an introduction. $2^{\text {nd }}$ edition Essex: Pearson Education Limited.

Ahmed, R.R., Ahmad S, (2014), "Pharmaceutical drug promotion in Pakistan: Issues in ethical \& non-ethical practices", Middle East Journal of Scientific Research, Vol. 20 (11): 1630-1640.

Martin, G.S. and Brown, T.J. (1990), "In search of brand equity: the conceptualization and measurement of the brand impression construct", Marketing Theory and Applications, Vol. 2, pp. 431-8.

Nunnally, J.C. and Bernstein, I.H. (1994), Psychometric Theory, 3rd ed., McGraw-Hill, New York.

Rangaswamy, A., Burke, R.R. and Oliva, T.A., (1993), "Brand equity and the extendibility of brand names", International Journal of Research in Market-ing, Vol. 10, No. 1, pp. 61-75.

Kotler, K.L., Armstrong, G., Harris, L.C. and Piercy, N., 2013. Principles of Marketing. European Edition. Harlow: Pearson Education.

Farquhar, Peter H. (1989) Managing brand equity. Marketing Research 1(3):24-33.

Lassar, W., Mittal B. , and Sharma A. (1995) Measuring Customer-Based Brand Equity. Journal of Consumer Marketing 12(4): 11-19.

Keller KL. (1993) Conceptualizing, measuring, and managing customer-based brand equity. Journal of Marketing 57(1): 1-22.

Aaker, D. A., \& Joachimsthaler, E. (2000). Brandleadership. New York, New York, United States of America: T he Free Press.

Keller, K.L. (2003) Strategic Brand Management. 2nd edition. Upper Saddle River, NJ: Prentice Hall.

Kril, J., 2013. Statistics and Facts about Online Shopping. Statists. [Online] Available

At:,http://www.statista.com/topics/871/online-shopping/>. [Accessed 16 June 2014]

Strauss, J. \& Frost, R. (2001) E-Marketing. Upper Saddle River, NJ: Prentice Hall.

Kaplan, A. M., \& Haenlein, M. (2009). Consumer use and business potential of virtual worlds: The case of Second Life. TheInternational Journal on Media Management 11(3).

Kaplan A. M. and Haenlein, M. 2010. Business Horizons: Users of the world, unite The Challenges and opportunities of Social Media . Volume 53, Issue1, January-February2010, Pages 59-68. [Online] Available at: <http://www.sciencedirect.com/science/article/pii/ S0007681309001232>. [Accessed 21 June 2014].

Neilsen, 2012. State of the Media: The Social Media Report. [Online] Available at:

$<$ http://www.neilsen.com/content/dam/corporate/us/en/reports-downloads/2012-Reports/The-Social Media Report-2012.pdf>. [Accessed 16 June2014].

Damian Ryan, Calvin Jones (2012). Understanding Digital Marketing: Marketing Strategies for Engaging the Digital Generation, Kogan Page Publishers 